View Article Online / Journal Homepage / Table of Contents for this issue

LING: ISOMERIC CHANGES IN THE PHENOL SERIES. 147

XIX.-Isomeric Change in the Phenol Series. I. The Action of Bromine on the Dibromonitrophenols.

By Akther R. Ling.

IN a paper by Dr. Armstrong (Jour. Chem. Soc., 1875, 520), entitled "Note on Isomeric Change in the Phenol Series," this author shows that parabromodiorthonitrophenol (m. p. $76^{\circ}$ ) is converted by mere warming with bromine into the isomeric orthobromoparaorthodinitrophenol (m. p. $116^{\circ}$ ). Thinking that isomeric change might also take place in other cases, Dr. Armstrong directed his attention to the dibromonitrophenuls, and found as the result of a preliminary experiment that when dibromorthonitrophenol (m. p. $117^{\circ}$ ) was heated with 
bromine a small amount of the isomeric dibromoparanitrophenol (m. p. $141^{\circ}$ ) was produced, together with a considerable quantity of at non-nitrogenous compound insoluble in alkaline solutions and $i n$ alcohol, but readily soluble in benzene, from which it crystallised in yellow six-sided plates and prisms melting above $200^{\circ}$. The same compound was obtained when dibromoparanitrophenol was similarly treated.

At the suggestion of Dr. Armstrong, I have undertaken the experiments recorded in this paper with the view of obtaining, if possible, some explanation as to the mode in which the change from an orthonitroparabromo- to a paranitro-orthobromo-derivative may be assumed to take place.

The non-nitrogenous compound, which is the ultimate product of the reaction between bromine and the dibromonitrophenols, was first examined, a quantity of the substance originally prepared by Dr. Armstrong keing used. Two closely agreeing bromine-determinations, together with the fact that it was found not to contain hydrogen, suggested that it was in all probability bromanil (tetrabromoquinone), $\mathrm{C}_{6} \mathrm{Br}_{4} \mathrm{O}_{2}$, a compound first described by the late Dr. Stenhouse (Jour. Chem. Soc., 1870, 6).

The numbers obtained for bromine are as follows :-

I. 0.2633 gram gave 0.4664 gram $\mathrm{AgBr}$.

II. $0.2581 " 0.4558$ "

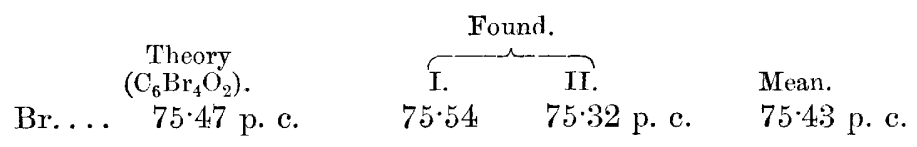

Stenhouse has shown that bromanil is converted by treatment with a 4 per cent. aqueous solution of potassium hydroxide into potassium bromanilate, which is a very characteristic salt:

$$
\mathrm{C}_{6} \mathrm{Br}_{4} \mathrm{O}_{2}+4 \mathrm{KOH}=\mathrm{C}_{6} \mathrm{Br}_{2} \mathrm{O}_{2}(\mathrm{OK})_{2}+2 \mathrm{KBr}+2 \mathrm{OH}_{2} .
$$

2 grams of the supposed bromanil, moistened with alcohol, was therefore added to a solution of caustic potash $(2 \cdot 4$ grams $\mathrm{KOH}+$ 60 c.c. $\mathrm{H}_{2} \mathrm{O}$ ) contained in a small flask; the mixture was oceasionally shaken during a period of five hours, at the end of which time the yellow crystals had disappeared, having given place to dark-purple crystals. Common salt was then added to precipitate that part of the salt which was dissolved in the alkaline solution. After being several times dissolved in water, precipitated with common salt, and finally recrystallised, the salt was obtained in a form agreeing with Stenhouse's description of potassium bromanilate :-

* The sodium chloride used in the precipitation of the salt was pure, and con. 
0.2469 gram gave $0 \cdot 1118 \mathrm{~K}_{2} \mathrm{SO}_{4}$.

$$
\begin{array}{cl}
\text { Theory } & \text { Found. } \\
\text { K } \left.\ldots \ldots \ldots \quad 1 \mathrm{C}_{6} \mathrm{Brg}_{\mathrm{g}} \mathrm{K}_{2} \mathrm{O}_{4}+\mathrm{H}_{2} \mathrm{O}\right) . & 20 \cdot 29 \text { per cent. }
\end{array}
$$

The melting point of the bromanil from the dibromonitrophenols was found to be $288^{\circ}$; a specimen kindly given me by Mr. Groves was found to melt at the same temperature.

The action of bromine on the dibromonitrophenols may therefore be represented by the following equation :-

$$
\mathrm{C}_{6} \mathrm{H}_{2} \mathrm{Br}_{2}\left(\mathrm{NO}_{2}\right) \cdot \mathrm{OH}+4 \mathrm{Br}_{2}+2 \mathrm{OH}_{2}=\mathrm{C}_{6} \mathrm{Br}_{4} \mathrm{O}_{2}+6 \mathrm{HBr}+\mathrm{HNO}_{3} .
$$

In order to throw light on the apparent isomeric change involved in the production of dibromoparanitrophenol, it was deemed expedient to try, first of all, the action of a mere trace of bromine on dibromorthonitrophenol; for this purpose the following experiments were made :-

I. 10 grams dibromorthonitrophenol was introduced into a bottle together with about 40 c.c. water and bromine in the proportion of $\mathrm{C}_{6} \mathrm{H}_{2} \mathrm{Br}_{2}\left(\mathrm{NO}_{2}\right) \mathrm{OH}: \frac{1}{10} \mathrm{Br}_{2}$; the stopper was then inserted, wired down, and the bottle heated in a pan of boiling water. The heating was continued for $3 \frac{1}{2}$ hours.

T'here was no change apparent, the product being entirely soluble in potassium carbonate solution, and giving only the red crystals of potassium dibromorthonitrophenol; these on treatment with acid gave a nitro-derivative which melted at the same temperature as before, viz., $117^{\circ}$.

II. 10 grams of the substance was heated with half a molecular proportion of bromine for three hours. A small quantity of bromanil, however, was obtained; the portion soluble in potassium carbonate solution appeared to be the unaltered nitro-compound; it melted as before at $117^{\circ}$.

III. 10 grams of the substance was heated with one molecular proportion of bromine for five hours. The insoluble portion being removed, red crystals of the apparently unchanged substance were deposited; these were not further examined. From the mother-liquors, however, some red crystals were obtained, which it could be discerned were contaminated with a yellow salt; as the quantity of the latter was very small, separation was not attempted.

IV. 10 grams of the substance was heated with one molecular proportion of bromine for $12 \frac{1}{2}$ hours. The liquid filtered from the insoluble compound deposited a brownish-yellow salt. No trace of tained no calcium or magnesium salts; the precautions recommended by Dr. Sten. house were not observed. 
the red salt which dibromorthonitrophenol yields was observed. A determination of potassium in the salt thus obtained gave $\mathrm{K}=16.44$ per cent. After recrystallisation, the following numbers were obtained :-

0.3098 gram gave 0.0972 gram $\mathrm{K}_{2} \mathrm{SO}_{4}=14.04$ per cent. $\mathrm{K}$.

0.2619 gram gave 0.1854 gram $\mathrm{AgBr}=30.20$ per cent. Br.

It was obrious from these numbers that I was dealing with anything but a pure compound; they clearly point, however, to the presence of a potassium monobromonitrophenol.

It appeared probable from the foregoing experiment that the alkaline extract must have contained a mixture of salts. Several experiments were therefore carried out under the same conditions as the last mentioned, in order to prepare a larger quantity of product. As the result of several such experiments, I not only obtained a quantity of a substance having much the same appearance as before, but ultimately by means of fractional crystallisation and purification with animal charcoal, I succeeded in isolating from the mixture, the salts of the three following compounds in a state of purity :-

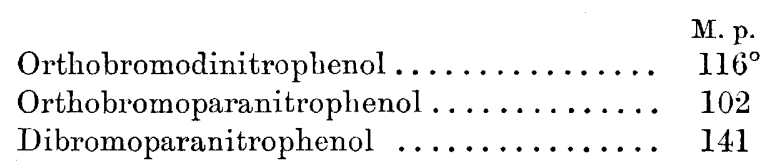

A small quantity of potassium bromanilate was also separated, which was undoubtedly produced by the action of potassium carbonate on the bromanil.

The numbers obtained on analysing the above-mentioned salts are as follows :-

\section{Potassium Brumodinitrophenol.}

0.2273 gram gave 0.652 gram $\mathrm{K}_{2} \mathrm{SO}_{4}$.

$$
\begin{array}{cl}
c & \text { Theory } \\
\left(\mathrm{C}_{6} \mathrm{H}_{2} \mathrm{BrN}_{2} \mathrm{O}_{5} \mathrm{~K}\right) . & \text { Found. } \\
\mathrm{K} \ldots \ldots \ldots \quad 12.95 \text { per cent. } & 12.84 \text { per cent. }
\end{array}
$$

It was found to be exceedingly difficult to obtain good numbers for bromine in this salt, as it is very apt to deflagrate when heated with lime in a tube, thereby causing a loss of bromine. A determination of bromine was therefore made in the phenol :-

0.1483 gram gave 0.1062 gram AgBr.

$$
\begin{array}{cl}
\text { Theory } & \text { Found. } \\
\text { Br........ } & \left(\mathrm{C}_{6} \mathrm{H}_{3} \mathrm{BrN}_{2} \mathrm{O}_{5}\right) . \\
30 \cdot 42 \text { per cent. } & 30.54 \text { per cent. }
\end{array}
$$




\section{Potassium Bromoparanitrophenol.}

0.2078 gram gave 0.0720 gram $\mathrm{K}_{2} \mathrm{SO}_{4}$.

$0 \cdot 1890$ gram gave 0.1359 gram $\mathrm{AgBr}$.

\begin{tabular}{|c|c|c|}
\hline & $\begin{array}{l}\text { Theors } \\
\left.\mathrm{C}_{6} \mathrm{H}_{3} \mathrm{BrNO}_{3} \mathrm{~K}\right)\end{array}$ & \\
\hline$\cdots$ & $15 \cdot 23$ per cent. & 15.54 per \\
\hline
\end{tabular}

That this salt was potassium bromoparanitrophenol was proved by the fact that on treating the phenol from it, dissolved in glacial acetic acid, with bromine, dibromoparanitrophenol was obtained, which was identified by taking the melting point and by converting it into the potassium-derivative, the light yellow crystals only being obtained.

\section{Potassium Dibromoparanitrophenol.}

It was unnecessary to analyse this salt; the compound obtained on treatment with acid being sufficiently characterised by its behaviour on heating, sharply melting with decomposition at $141^{\circ}$. Furthermore, it was previously obtained by the same means by Dr. Armstrong, as stated in the paper before referred to.

About two-thirds of the crude mixture of salts consisted of potas$\operatorname{sinm}$ bromodinitrophenol; the remainder was chiefly potassium bromoparanitrophenol, potassium dibromoparanitrophenol being the least abundant.

In order to determine approximately the amount of bromanil formed, two rough experiments were made with dibromorthonitrophenol, and one with dibromoparanitrophenol. 10 grams dibromorthonitrophenol was heated as before with 5.5 grams bromine. The crude bromanil was collected on a filter and weighed: 4.5 grams was the weight found. Theoretically there should have been only 3.6 grams. In the second experiment 10 to 11 grams bromine was used; 9.5 grams crude bromanil was obtained, the theoretical amount being $7 \cdot 2$ grams. 10 grams dibromoparanitrophenol, heated with 5.5 grams bromine, yielded 3.3 grams crude bromanil, being just under the weight required by theory.

The alkaline extract from this last experiment was found to consist of a mixture of the same salts in about the same proportions as that obtained from dibromorthonitrophenol.

In each case, the bromine had almost all disappeared, and a considerable amount of gas--nitric oxide- escaped on releasing the stopper of the bottle.

The foregoing results serve both to confirm and to extend Dr. Armstrong's conclusion that the action of bromine on dibromortho- 
nitrophenol is attended with isomeric change, for not only has dibromoparanitrophenol been obtained, but also monobromoparanitrophenol.<smiles>O=[N+]([O-])C1CC(Br)CC(Br)C1</smiles><smiles>O=[N+]1CCC(O)CC1Br</smiles><smiles>O=[N+]1CCC(Br)C(Br)C1</smiles>

Dibromorthonit
trophenol.

Bromoparanitro-

Dibromoparanitrophenol.<smiles>O=[N+]1CC(Br)CC([N+](=O)[O-])C1</smiles>

Bromodinitrophenol.

The production of the latter shows also that the formation of bromanil takes place partly at the expense of the bromine of the dibromonitro-compound, a conclusion in harmony with the fact that more bromanil is obtained than corresponds with the amount of bromine used, although it must not be forgotten that the nitric acid which, it may be presumed, is initially formed from the $\mathrm{NO}_{3}$ displaced, would serve to render a considerably larger amount of the bromine available than is indicated by the equation previously given. The experiments throw no light on the precise manner in which the isomeric change takes place; but the conditions are such that it would appear to be almost beyond question that it is a case of true intramolecular change.

I purpose extending my experiments to other nitro-halogen phenolderivatives, in the hope of obtaining further evidence in explanation of the isomeric change.

In conclusion, I have to express my thanks to Professor Armstrong for the many valuable suggestions, and the great help he has given me whilst engaged in this work. 